\title{
Mand nok?
}

\section{- Om kropsliggørelser og maskulinitetsfortællinger i transkønnedes video blogs på YouTube}

Af Tobias Raun

Mange transkonnede bruger YouTube som platform til at fà skarm-og taletid. Gennem video blogs (vlogs) dokumentever og diskutterer transmand egne kropslige transformationer og psykosociale forestillinger om køn. Hvilke forestillinger om mand og maskulinitet kommer til udtryk? Hvilke forskellige former for maskulinitet er onskvardige og bvilke er ikke? Hvordan kropsliggøres maskulinitet og bvordan bliver kameraet et redskab $i$ denne "bliven mand"?

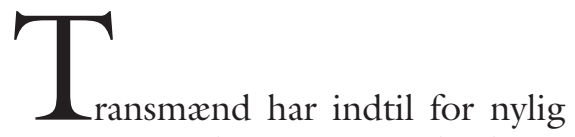
været en meget usynlig gruppe. Faktisk var den første repræsentation, jeg - og sikkert mange andre - stødte på Brandon Teena i filmen Boys Don't Cry. Filmen både nærede og bristede mange in spe transmænds drømme, idet den med al tydelighed viste, hvor farligt det kan være at agere mand, når man har et kvindeligt kropstegn.

Indenfor forskningen i transkønnethed er transmænds liv og erfaringer også underbelyste (Forshee 2008: 223). Og inden for mande- og maskulinitetsforskningen er transmænd en overset gruppe (Green 2005: 291). Der mangler altså forskning i transmænds forståelse og oplevelse af sig selv som mænd - og i deres audiovisuelle (selv)repræsentationer. Det er dette hul, som denne artikel bidrager til at dække ved at undersøge, hvordan YouTube-generationen forholder sig til maskulinitet. YouTube er et oplagt sted at undersøge dette, fordi det er et transnationalt forum for brugerskabte videoer lavet af transkønnede selv. 


\section{YOUTUBE SOM VIRTUELT FELTSTUDIE}

Et stigende antal transkønnede har en såkaldt "personal channel page" på YouTube, hvor de oploader brugerskabte videoer af sig selv, der dokumenterer og diskuterer deres kønslige transition. I denne artikel tager jeg afsæt i tre transmandlige vloggere: James, Tony og Mason, der både er repræsentative i forhold til feltet (hvor der er en stærk overvægt af hvide amerikanske vloggere), men som samtidig også udviser en diversitet i forhold til deres køns-og seksualitetsperformativer og måder at bruge vloggen som medie på. Der er tale om nogle 'gamle' såvel som 'nyere' brugere, der forholdsvis hurtigt popper op ved en simpel søgning efter materiale inden for kategorien 'transgender'. Ligeledes opfylder de en række andre kriterier, som jeg har opstillet, såsom at brugerne skal være over 18 år, at de skal have mere end 30 uploads, at de fortsat skal være aktive, at det skal fremgå af deres vlogs, at de identificerer sig inden for et transmaskulint spektrum og gør brug af diverse kropsligt modificerende teknologier såsom hormoner $\mathrm{og} / \mathrm{eller}$ operationer. Jeg fokuserer således på dedikerede trans vloggere, hvor det er muligt at spore en udvikling i den enkeltes udtryk og narrativ (medie-og identitetsmæssigt) og på den gruppe af transkønnede, der i medicinske termer diagnosticeres som "transseksuelle", en diagnose der fortsat står registreret på WHOs liste over psykiske lidelser. Selvom YouTube er et offentligt tilgængeligt site, og jeg har været i dialog med vloggerne om min forskning, har jeg valgt at anonymisere dem for ikke at bidrage til en yderligere personlig eksponering, som jeg ikke kan vide, hvilke konsekvenser vil få. Som Heidi Mckee og James Porter gør opmærksom på, bør en internetforsker altid overveje "the effects of "bringing the public" to a particular online $[\ldots]$ community $[\ldots]$ which, because of the sheer size of the Internet, might otherwise have remained unnoticed" (Mckee og Porter 2009: 89). Jeg positioner mig metodisk indenfor det forsknings- felt, der ofte benævnes 'virtual ethnography' (se Hines 2000, Lange 2007, Boyd 2008), og som i mit tilfælde involverer online- observationer, indholds- og visuelle analyser af vlogs samt semi-strukturede interviews med vloggerne. Min undersøgelse er i forlængelse heraf fokuseret på den kulturelle dimension af internettet, altså transvlogging som en særlig kulturel gøren affødt af og i dialog med øvrige diskursiveringer af transkønnede - ikke mindst den psykomedicinske patologisering. Jeg ser disse trans vlogs som en virtuel kulturel praksis samtidig med, at jeg også betragter dem som kulturelle artefakter/representationer.

\section{ET TRANSTEORETISK GREB OM VLOGGEN}

Mine læsninger er informeret af et ønske om at præsentere den enkelte vloggers kønslige selvopfattelse og udtryk uden at fremlæse nogle som mere 'rigtige' eller 'subversive' end andre. Dette kan være en udfordring, dels fordi der indenfor transbevægelser/fællesskaber (herunder også på YouTube) er mange forskellige og til tider konkurrende opfattelser af, hvad det vil sige at være (trans)mand. Dels har jeg ofte fra forskningsmæssig side oplevet (på konferencer eller til forskningsfremlæggelser), at forskere efterlyser og er investeret i, hvilke af trans vloggernes selvfremstillinger der er subversive og hvilke der er norm(re)producerende. Samt om jeg som forsker er tilstrækkelig kritisk overfor samme. Det er interessant, at der synes at være et implicit krav om, at transkønnede bør være mindre kønsnormative og heteronormative i deres maskulinitetsciteringer. Samt en antagelse om, at god forskning beror på en kritisk dekonstruktion, hvor forskeren skal 'afsløre' underliggende antagelser og normativiteter. "[U]nveiling have become the common currency of cultural and historicist studies", som Eve Kosofsky Sedgwick skriver: (Sedgwick 2003: 143). Og som hun videre argumenterer, er denne form for "tracing-and- 
exposure project" blevet "a mandatory injunction rather than a possibility among other possibilities" (Sedgwick 2003: 124$125)$.

Jeg er ligeledes flere gange stødt på sådanne læsninger fra ellers velmenende queer-forskere (se bl.a. Johnson 2007, Kaufmann 2010), hvorfor det er vigtigt at dvæle et kort øjeblik ved, hvordan sådanne læsninger positionerer forskeren og det udforskede. Mine forbehold går således på, at forskeren implicit castes i rollen som det umarkerede vidende subjekt, der kan 'afsløre' huller, selvimodsigelser og bagvedliggende ideologier (oftest heteronormativitet) i selvfremstillingerne (a la Johnson), mens de transkønnede fremstår som ukritisk nedsunkne i falsk bevidsthed. Ligeledes tildeles den individuelle transhistorie blot allegorisk status, idet den udelukkende anvendes til at italesætte forskellige teoretiske "plots" (ala Kaufmann). Mine læsninger er i et opgør hermed teoretisk-metodisk informeret af Transgender Studies, der netop fokuserer på at synliggøre og betone transpersoners egne (kropslige) erfaringer og selvrepræsentationer (Namaste 2000, Prosser 1998). Der er, som Sandy Stone påpeger, en stærk historisk tradition for, at "[ $\mathrm{t}]$ he people who have no voice in this theorizing are the transsexuals themselves" (Stone 2006: 229). Dette gør sig i et vist omfang fortsat gxldende, da det overvejende er ciskønnede, ${ }^{1}$ der fortæller om og fortolker på transkønnedes livshistorier. Der er en blindhed i forhold til, hvilken magt der ligger heri, og som svarer til, at det overvejende er mænd der forsker i kvinder. Der er ligeledes en mangel på forskning, der viser polyvokaliteten i transkønnedes fortællinger og ikke mindst analyseret af transkønnede selv.

Mit begrebsapparat hentes fra Judith Butler, herunder forståelsen af heteronormativitet som regulerende ramme og køn som performativ indstiftet tilblivelse (Butler 1990, 1993, 2004). Dette anvendes dog under inspiration af det eksisterende fæno- menologisk informerede empiriske arbejde om transmænd (Devor 1997, Cromwell 1999, Rubin 2003) til at indkredse vloggernes individuelle fremstillinger og forhandlinger af køn snarere end de mere overordnede strukturer/diskursiveringer.

\section{VIDENSDELING FRA EN \\ DOKUMENTATIONSLYSTEN VLOGGER: JAMES}

“I document everything!” (James 2009)

James er i skrivende stund 26 år og bosiddende i Californien i USA. Han var blandt den første bølge af transkønnede, der tilmeldte sig YouTube. Han startede således allerede i foråret 2006 med at uploade videoer, da han endnu boede i Florida. I den første video sidder han betuttet på sit værelse, mens hans daværende (kvindelige) kæreste nervøst giver ham en testosteron injektion (2006).

Han dokumenterer minutiøst signifikante begivenheder og følelsesregistrer, han har gennemgået i forbindelse med sin transition. Morgenen før sin brystkasseoperation ser vi en henholdsvis grædende og grinende James, der siger: "I don't even know what to say, I'm so emotional [...] We [James og en ven, TR] are gonna be boys [...] it's gonna be so cool!" (2007). Vi er også med helt inde på operationsstuen, da han vågner fra operationen, og senere kan vi følge ham til check up med kirurgen, første gang på stranden uden trøje, dagen han får sit juridiske navneskifte, sin første tatovering og mange andre markante begivenheder. Udover en ekstrem dokumentationslyst, emmer hans vlogs også af lyst til at dele og udveksle erfaringer, tanker og viden om transrelaterede spørgsmål af både juridisk, medicinsk og kulturel karakter. Vloggen bliver et redskab, der hovedsagelig anvendes til at dokumentere, arkivere og videreformidle informationer om transkønnethed - ting fortælles frem, holdes op for kameraet eller henvises til via links. 
James er en af de mest populære transfyre på YouTube, ikke mindst fordi han så længe har været en meget aktiv vlogger. Han er således en 'micro-celebrity' (Senft 2008), kendt af folk indenfor et trans eller queer-miljø, der ofte henvender til ham med spørgsmål og kommentarer. Som Theresa Senft skriver: "on the Web, popularity depends upon a connection to one's audience, rather than an enforced separation from them" (Senft 2008: 26). For at vedligeholde denne popularitet er han altså nødt til kontinuerligt at forhandle med sit 'publikum' om, hvad han betyder som person og som produkt. Dette fordrer også nogle ting af ham som rollemodel, hvilket han reflekterer over i en vlog: "I just realised, so many people look up to me and what would it mean if I hurt myself or kill myself, you know it would just show this whole population that yeah, this thing does beat you and its hard to get through" (2009). At være et velkendt ansigt på YouTube gør altså, at James dels føler et socialt ansvar for at tale åbent om sine psykosociale oplevelser af (trans)køn - også de dårlige, og dels ønsker at gøre det på en måde som ikke bekræfter de patologiserende og offerliggørende fortællinger om transkønnethed, som er herskende.

\section{ET HAD-KÆRLIGHEDSFORHOLD TIL KØNSBINARITETEN}

For James er det vigtigt til fulde at kunne inkarnere og fremtræde som mand, hvilket både er et kropsligt, adfærdsmæssigt og seksuelt spørgsmål for ham. James betoner, at de vigtigste maskulinitetsparameter for ham er penis, dyb stemme (2009), at kunne urinere stående (2008), skægvækst (2009) og en flad brystkasse. Han fremtræder således ofte med skæg og uden trøje, når han vlogger, således at hans slanke og let muskuløse brystkasse og mave er fuldt synlig. James synes at have en stærk investering $i$, at kroppen skal være entydig maskulint kønnet og at den skal kunne udføre vis- se (hetero)seksuelle praksisser. Hans kønsidentitet er seksuelt bundet op på at indtage en 'maskulin rolle'. Hans erkendelse af sig selv som trans var også foranlediget af et ønske om at være kvindernes "boyfriend" som han siger: "I just had to date girls and it slowly moves into taking a male role with them and then having to be in that role all the time" (2009). Hans kærester er alle "straight identified" (2010), hvilket synes at virke bestyrkende for hans maskuline kønsidentitet og deres interne kønspositionering. Dog vækker det også en nagende tvivl hos ham om ikke at være 'mand nok' i forhold til hendes tidligere ciskønnede mandlige partnere ("Am I man enough? Do I act like them, do I do the same thing like them?" (2008)). Det er i forlængelse heraf vanskeligt for ham at forene sig med, at han engang havde en kvindekrop: "It fucks me out that I had the same parts as my girlfriend $[\ldots]$ and that we both had to use the same bathroom, that fucks me out!" (2008) siger han og vrænger i væmmelse, mens han sidder med benene spredt til hver side i en lænestol i bar mave og shorts. Det er fraværet af en entydig mandlig krop og historie, der er kilde til mange af de problemer, han oplever med sig selv og med andre. Han føler sig hjemsøgt af sit eget tidligere selv og forrådt af sin krop i puberteten (2008).

James identificerer sig som en "queer heteroseksuel” (2009). 'Heteroseksuel' angår hans begær, mens 'queer' går på hans selvidentifikation som en lidt alternativ maskulinitet (2011). Som han siger, er han ikke den høje, store, øldrikkende, fodboldelskende fyr men istedet "this nerdy, beatnik, leftist, this counterculture type dude" (2009). Hans alternative maskulinitet affødes også af det, han ofte lidt abstrakt betegner som "lower stuff" eller "not to have whatever normal functioning equipment down there" (2008). Dette er et evigt tilbagevendende tema, som han prøver at håndtere på forskellige måder i løbet af de seks år han vlogger. Det er i særdeleshed 
økonomi og manglen på optimale operative løsninger, der afholder ham fra at fă foretaget indgreb (2009). På den ene side forsones han med sin nuværende pik gennem læsning af utallige bøger om mænd og maskulinitet og gennem sine nye ciskønnede mandevenner, der făr ham til at erkende at "part of being male - any kind of male [...] is coming to accept your penis, its size, its limitations, its functions, its appearance [...] so we are not the only ones" (2010). På den anden side er investeringen i netop denne kropsdel så stærk, at han kontinuerligt rammes af "dysphoria", som han betegner det.

James udtrykker således en stærk omend ambivalent investering $\mathrm{i}$ et binært kønssystem med stabile kønslige positioner og en tiltrækning/seksualpraksis rettet mod det modsatte køn. Transkønnetheden er i forlængelse heraf noget han både favner og frusteres over, hvilket ikke mindst illustreres i den måde han omtaler sine ar efter brystkasseoperationen. Først udtrykker han bekymring, da de gør ham visuelt synlig som trans (2007) men senere laver han en vlog, hvor han vandrer igennem byen uden trøje, mens han viser sine "battle scars to everyone". Her reformuleres betydningen af at være kropslig synlig som transkønnet fra at handle om ikke at være 'rigtig mand' til netop at være et emblem på maskulinitet, idet arene bliver et vidnesbyrd om hans psykiske og fysiske kvaler: "Hell yeah, I went through all that shit" (2010). Hans vlogs fremstår som digitale selvbiografier, der kredser om og bliver en katalysator for at finde stolthed $\mathrm{i}$ sin transmaskulinitet samtidig med, at han kontinuerligt udtrykker en længsel efter og stærk investering i til fulde at kunne inkarnere og fremtræde som en (heteroseksuel) mand.

\section{VIDEODAGBØGER FRA DRENGEVÆRELSET: TONY}

"I have found out that it is really helping me to document things" (Tony 2009)
Tony er 20 år og fra nordøstengland. Han tilmeldte sig YouTube i foråret 2009 og introducerede sig som en 'pre-op, pre-T transboy' (2009). Han går i college og bor hos sin mor og stedfar, da han starter med at vlogge men flytter senere hjemmefra. Han vlogger for det meste fra sit værelse, der er fyldt med plakater og oftest lettere rodet.

Hans vlogs har et meget dagbogsagtigt præg, idet de virker som små opdateringer, der skal indfange hans aktuelle fysiske og emotionelle tilstand. De virker forholdvis uredigerede og er oftest optaget med et stillkamera, der i en uforfinet billede- og lydkvalitet optager, mens han monologisk taler. Ofte kører der et fjernsyn i baggrunden eller man kan høre lyden af musik - ingen af delene virker dog som bevidst indkorporerede effekter. Til tider kommer hans mor ind i rummet, mens han er ved at optage, eller man kan høre hans forældre råbe noget til ham i baggrunden. Ofte er han ikke helt klar over, hvor meget batteri, der er tilbage på hans kamera, så han gentagende gange må springe om bag kameraet for at se. Dette giver hans vlogs et hverdagsligt, ligefremt og uhøjtideligt præg. Han virker ofte lettere 'uforberedt' og adspredt, som om vlogging på den ene side er noget han "bare gør" for sin egen (tidsfordrivs) skyld, men på den anden side en social aktivitet, rettet mod et publikum, som han spørger til råds og også selv giver råd (bl.a. om 'passing', at lave en 'packer', 2 'STP'3 og 'binding'4).

De første mange vlogs skildrer den vanskelige tid, da han lige er 'sprunget ud' som transkønnet og venter på at få testesteron igennem NHS (den engelske offentlige sygesikring). I flere vlogs virker han frustreret og ked af det, men som jeg andetsteds har argumenteret for bliver vloggen et terapeutisk redskab, som han bruger til at kommunikere sine tanker og frustrationer, samtidig med at det giver ham følelsen af, at der er nogle, der ser og hører ham (se Raun 2011). Som han siger: 
"I thought this would be the best way to get it out because I don't feel that I am able to cry on my own. I have to be able to break down to somebody and it turns out that lucky person would be you [han ser ud på beskueren, TR]. And I want to be able to look back on this and say I have come a long way" (2009).

Han takker også i flere vlogs for den støtte, han modtager fra transfællesskabet online og for at kunne få indblik i, hvordan det er for andre transfyre at gå i transition. Da han senere starter på testosteron centrerer hans vlogs sig om de fysiske forandringer, som han løbende fortæller om og fremviser til kameraet.

\section{KOMFORTABELHED SOM ET CISKØNNET PRIVILEGIE}

Tony italesætter i de første vlogs (før testosteronen har maskulinieret hans krop) en følelse af kropslig og social disorientering. Hans første vlogs vidner således om, hvor meget det betyder for ham at passere som mand, og hvor meget tid og energi han bruger på at tænke over og justere sin fremtoning. Selv da han bliver mast under en koncert og ikke kan få luft er han mest af alt bekymret for, om redningsfolkene skal opdage hans 'binder' (2009). Køn italesættes som et tids- og energikrævende forhandlingsarbejde, idet han konstant må afstemme sin fremtoning efter, at han måske netop ikke 'passerer', hvorfor han eksempelvis ikke kan anvende en for stor 'packer'. Han forudser således allerede den hån, han kunne blive udsat for: "Hahahaha - you got 3 socks down there trying to be a man" (2009). Hos Tony er spørgsmålet om genkendelse som mand afgørende og knyttet til en række affekter, ikke mindst følelsen af (u)komfortabelhed. Sara Ahmeds affektteoretiske greb er i forlængelse heraf anvendeligt i forhold til at indkredse, hvorledes heteronormativiteten producerer særlige affekter. Ahmed bruger den kom- fortable lænestol som billede på at passe ind i normen, hvilket knyttes til følelsen af (u)komfortabelhed - hvis stolen passer til ens krop lægger man ikke mærke til den, men det gør man hvis den ikke passer. At være ukomfortabel er således en kropslig følelse af ubehag samtidig med, at det er en følelse af socio-geografisk disorientering “one's body feels out of place, awkward, unsettled" (Ahmed 2004: 148). Det er en følelse af ikke at passe ind, ikke at blivet taget imod af sine omgivelser, hvorved netop bevidstheden om kroppen som en grænse skærpes (Ahmed 2004: 148). Tony italesætter testosteronen som et stof, der gør ham "comfortable with my body", hvorfor han efter eget udsagn ikke længere er så "paranoid" (2009). Han passerer nu som mand: "I can get on a bus, sit, put my music on and not think oh maybe that person is looking at me thinking is that a boy or a girl" (2009). Også James italesætter den medicinske transition som en (gen)erobring af sin krop som et beboeligt og komfortabelt sted (2009). Som han siger: "I feel so much more comfortable seen as a guy, adressed as a guy, navigating the world as male and being in relationships as a male with a woman" (2009). At passere producerer altså en følelse af komfortabelhed og af lettelse hos James såvel som Tony. Samtidig er følelsen af komfortabelhed ikke uden visse sprækker af ukomfortabelhed, da det at passere oftest forudsætter en usynliggørelse og tavsliggørelse af transidentiteten - ciskønnethed er således den altomfattende antagelse. Som Tony siger:

"I am just different than the average person and how am I going to cope with living an average life? How do I get from being a boy who used to be a girl to just being a guy who gets on with his life?" (2010).

Tony italesætter således en følelse af 'hjemløshed' i denne usynlighed og en skuffelse over, hvor fraværende og marginaliserede transkønnede er til mange LGBT-begiven- 
heder. Til Pride er hans medbragte transflag således "the only trans thing that I have seen all day beside from myself" (2009). Som Vivianne Namaste har påpeget domineres LGBT-fællesskaber fortsat af 'lesbiske' og 'bøsser', hvorfor transkønnedes ikke inkluderes på egne præmisser. Transmænd inkluderes således hovedsagelig, hvis de i deres kønslige identitet ikke abonnerer på en for entydig maskulin selvfremførelse, der hurtigt aflæses som udtryk for sexisme og misogyni (Namaste 2005: 53-54). Tonys selverklærede seksuelle orientering er biseksuel, dog med en præference for kvinder. Som han siger er han halvfjers procent til kvinder og tredive procent til mænd (2009) - fysisk tiltrukket af mænd, men kan ikke forestille sig at være i et forhold med dem (2011). Han italesæetter i forlængelse heraf en stigende afstandstagen til det, han benævner "the queer scene", dels pga. den konstante problematisering af kønskategorierne og dels fordi han oplever at transfyre fetisheres - af bøsserne som et eksotisk begærsobjekt og af de lesbiske som blot en radikalisering af en butch identitet (2011). I begge tilfælde synes det at være Tonys hårdt tilkæmpede identitet som mand, der sættes spørgsmålstegn ved. Tonys vlogs har en dagbogslignende karakter og kredser om den hverdagslige følelse af (u)komfortabelhed, der aflejrer sig i og på den transkønnede krop gennem mødet med offentlige instanser og sociale andre.

\section{SURREALISTISKE VIDEOVÆRKER: MASON}

"Without that mirroring that this camera gives you I am not sure it's really possible to transition fully" (Mason 2010)

Mason er en 44-årig vlogger, der i skrivende stund er bosat i sydstaterne i USA. Han er uddannet psykolog og har arbejdet med transkønnede, men er ikke længere praktiserende. Han påbegyndte sin egen transition i 2007, hvor han startede på testosteron og fik lavet en brystkasseoperation. De første videoer var ikke tiltænkt YouTube, men i stedet kærlighedserklæringer til den daværende (mandlige) kæreste og egne dokumentationer af og refleksioner over transitionsprocessen. Han betegner sig selv som en "latecomer to YouTube" (2010), idet han først tilmeldte sig i efteråret 2010, hvor han uploadede en masse af sine tidligere videoer. Mason opsøgte YouTube transfællesskabet, fordi han var terapeut og ikke ønskede at gøre brug af de transressourcer/ supportgrupper, der var i hans område, hvor han ville møde en masse af sine klienter (2010).

De fleste af hans vlogs er meget æstetisk formfuldendte, holdt i sort/hvide nuancer, og med en hyppig brug af effektfuld baggrundsmusik, der sætter stemningen, og hvis tekst understreger den følelse eller problemstilling, som tages op. Billedsiden er ofte lettere surrealistisk, og han arbejder meget bevidst med at komponere og sammensætte forskellige billedudtryk således, at billeder af ham selv bearbejdes og sættes sammen med billedmateriale hentet andre steder fra (især film og kunst). Det sprogligt poetiske er også en væsentlig ingrediens, hvorfor man ofte hører selvforfattede tekster læst op i en form for voice-over af ham selv eller skrevet hen over skærmen. Hans vlogs præges af intimitet og intensitet - han er ofte tæt på kameraet, som han agerer og taler direkte ind i med et nærværende, intenst og ofte lettere flirtende blik. Vloggen er tydeligvis et (æstetisk) eksperiment og et reflektionsrum for ham. Han udforsker sin egen (køns)identitet, tænker og erkender med/igennem videomediet. Der er samtidig noget meget kommunikativt over hans vlogs, idet han ofte responderer på andres vlogs og kommer med opbakkende kommentarer og gode råd.

\section{QUeER COLLAGER}

Mason er en selverklæret kønsterrorist, der i sin introduktionsvideo skifter mellem at 
være $\mathrm{i}$ henholdsvis mandlig og kvindelig 'drag' til tonerne af Debbie Harrys æggende stemme fra punk/new wave-bandet Blondie. De forskellige kønslige performances understreges af de forskellige billedkvaliteter, der det ene øjeblik er smalfilmslignende og det næste øjeblik afløses af kontrastfyldte sort/hvid billeder (2010). Som han i en senere vlog siger: "I'm not a traditional guy, I never will be" (2010). Mange af hans vlogs kredser om at definere en kønsidentitet, som han kan genkende sig selv i, da netop kategorien mand ikke er dækkende for ham. Mason definerer sig, modsat James og Tony, i direkte opposition til et binært kønssystem med selvvalgte prædikater som "genderqueer", "genderqueer feminist", “a femme FTM" og “dragqueen daddy", der alle ifølge ham handler om ikke at lukke muligheden for at bebo både det feminine og det maskuline 'rum' i både kønslig og seksuel forstand. Han efterstræber en maskulin kodet krop gennem medicinske interventioner og vægttræning, men italesætter derudover en stærk kritik af mange (heteroseksuelle) maskulinitetsformer- og kulturer, der affejes som misogyne (2011). Hans selverklærede "queer" kønsidentitet er stærkt knyttet til en ikke-normativ begærsøkonomi som selverklæret "pansexual" eller "a transfag [...] who is still attracted to women" (2011). Mason iscenesætter sig selv og sit parforhold som et kønsligt flydende rollespil i konstant flux, hvor ikke mindst videomediet spiller en vigtig rolle. Ham og kæresten laver således videoer til hinanden i forskellige former for "drag" og med stærke seksuelle undertoner, som uploades på YouTube. Han udtrykker således begejstring for at have fundet en kæreste som "just wants to bake me cakes but also wants to be tied to my bed". Senere i samme vlog ser han intenst og flirtende ind i kameraet, mens han siger, at kæresten giver ham lyst til at "put on my liquid eyeliner and my high heels and my apron and cook something for him, make him a potroast or something" (2011). For- skellige former for teknologier og offentlige rum tages altså aktivt i besiddelse og bidrager til et seksuelt såvel som et identitetsmæssigt spil. Hans vlogs synes således ikke blot at være et forsøg på at queere transmaskuliniteten, men også YouTube som offentligt rum. Han synes således både kønsligt og seksuelt investeret i en identitet som “outlaw" (2011). Hans fremtidige giftemål med kæresten italesættes derfor på den ene side som "stupid" og "retro-romantic" i tråd med en queerteoretisk kritik af ægteskabet som institution (se fx Warner 2000), men på den anden side fastholder han, at et giftemål ikke vil ændre på, at de er et "genderfucked couple", som er "queering americana” (2011). Mason skandaliserer, seksualiserer og intimiserer i én og samme bevægelse sit forhold. Vloggen synes at blive et medie, hvorigennem han kan (gen)finde eller (gen)forhandle et forhold til sin rekonfigurerede krop som et seksuelt aktiv. Samtidig fungerer virtualiteten som et "safe space" i forhold til et fysisk geografiske rum og i forhold til at turde gøre krav på en "outlaw" position (2011). Som han siger: 'I do enjoy not being a typical dude, but it comes with a prize too' (2010).

I tråd med Kate Bornsteins fragmentariske og manifestagtige selvbiografi Gender Outlaw: On men, Women and the Rest of Us modsætter Masons vlogs sig en traditionel teleologisk narrativ struktur om transseksualitet. Som han siger: "I was never one of those traditional stories you see out there" (2011). Hans fortalte og fremviste identitetsprojekt retter sig således ikke mod et entydigt og koherænt maskulint narrativ, men er snarere en udfordring af selvsamme. Han påpeger: "who I am is a little more complicated than male or female" (2011). Visuelt ynder han også at iscenesætte seksualiserede og kompositte kønsudtryk, såsom i en vlog der indledes med, at han lukker døren ud til gaden og låser som skulle der foregå noget særligt hemmeligt/lyssky, hvorefter han går i gang med et sminke sig til Lady Gagas "Bad Romance”. Kameraet 
positioneres som et spejl, som han kigger ind i for at lægge makeup - og som han poserer $\mathrm{i}$ forhold til, mens han leger med at tage sit tøj delvis af og på. Skjorten tages af og under den viser der sig en strop-top, der ligeledes tages af således, at hans brystkasse blottes, alt imens han prøver et diadem over sit korte mørke hår. Hele seancen sluttes af med følgende tekst, der står med hvidt på sort baggrund: "On any given day, I transition from female to male, to female again, to something unknown. Transition isn't about following rules" (2010). Mason dyrker således transkønnethed som en bevægelse mellem og på tværs af kategorier uden et på forhånd fastlagt slutpunkt. Eller som Bornstein skriver:

"[B]oth my identity and fashion are based on collage. You know - a little bit from here, a little bit from there? Sort of a cut-and-paste thing $[\ldots]$ It's a transgendered style, I suppose" (Bornstein 1994: 3).

Masons selvdefinitionsprojekt og opgør med traditionelle teleologiske transnarrativer lægger sig dermed i forlængelse af transforfattere, -kunstnere og -aktivister som Kate Bornstein, Del LaGrace Volcano og Leslie Feinberg.

\section{EXIT: MASKULINITET IN TRANSIT}

James, Tony og Mason præsenterer forskellige audiovisuelle fortællinger om og forhandlinger af, hvad det vil sige at være (trans)mand. Vloggen bliver en måde at fortælle deres livshistorie og redegøre for deres kønsforståelse i en mere kompleks version end det 'masternarrativ', der fordres dels fra psyko-medicinsk hold, 5 hvor diagnosticering og patologisering er de altomfattende omdrejningspunkter. Og dels fra en mainstream medierepræsentation, der tjener den ikke-transkønnede værts og seers nysgerighed, hvorfor den transkønnede må forklare sig og gøre sig forståelig i sin andethed (Namaste 2005: 46-49).
Som jeg påpegede indledningsvis er det reducerende at læse disse vloggers selvfortællinger-og iscenesættelser udfra parametrene subversion/norm reproduktion. Jeg introducerer i stedet (u)komfortabelhed (Ahmed 2004) som et anvendeligt begreb til at indfange det komplekse mellemværende, som de giver udtryk for at have med deres krop, sociokulturelle normer om køn og seksualitet samt deres relation til andre mennesker. Dermed bliver det ikke et spørgsmål om, hvorvidt enkeltpersoner bryder med eller understøtter normen, men snarere hvordan normen producerer og virker igennem følelser af (u)komfortabelhed. Denne følelse af ukomfortabelhed figurerer hos James og Tony som en angst for/følelse af ikke at være mand nok. Deres vlogs fremstår således som et redskab til at diskuttere denne følelse og til at skabe maskulinitetsbestyrkende narrativer for sig selv (og andre transmænd). Hos Mason knyttes følelsen af ukomfortabelhed specifikt til kroppen i form af "a life long dysphoria with my body" (Mason 2011) og en vægring imod et binært kønssystem. Hans vlogs fremstår som et redskab til at udfolde et 'queer' køns-og seksualitetsprojekt, hvor han både kan eksperimentere med sin egen (køns)identitet og kritisere forestillingen om ciskønnethed og heteroseksualitet som naturlige predispositioner.

\section{Noter}

1. At være ciskønnet vil sige, at man identificerer sig med det køn, som man juridisk er blevet tildelt ved fødslen og med det kropstegn, som man er født med.

2. En 'packer' er en penis-lignende genstand, som mange transmænd anvender for at give "en bule i buksen”og følelsen af at have en penis. Mange trans vloggere laver vlogs om, hvordan man kan lave sin egen "packer" og dermed spare penge, eller hvor man kan købe de bedste og billigste.

3. En STP er en form for 'protese', som nogle transmænd bruger til at kunne urinere stående, nogle gange sat sammen med en 'packer'.

4. En 'binder' er stof, tape eller lignende, der an- 
vendes af mange transmænd til at give indtryk af en flad brystkasse. Transmændene laver den enten selv eller køber den pre-fabrikeret.

5. Historierne skal matche følgende kriterier:

"There must be evidence of a strong and persistent cross-gender identification, which is the desire to be, or the insistence that one is, of the other sex (Criterion A). [...] There must also be evidence of persistent discomfort about one's assigned sex or a sense of inappropriateness in the gender role of that sex (Criterion B) [...] To make the diagnosis, there must be evidence of clinically significant distress or impairment in social, occupational, or other important areas of functioning (Criterion D)". (DSM IV 1994, 532). Dette udøver, som bl.a. Judith Butler og Jay Prosser har skrevet om, sin egen form for sociale pres for den transkønnede, hvis livshistorie skal reduceres til en bestemt skabelon og som også må se sin selvdefinition blive karakteriseret som patologisk (Butler 2004: 75101, Prosser 1998: 99-134).

\section{LITTERATUR}

- Ahmed, Sara (2004): The Cultural Politics of Emotion. Edinburgh University Press, Edinburgh. - Bornstein, Kate (1994): Gender Outlaw: On Men, Women, and the Rest of Us. Routledge, New York.

- boyd, danah michele (2008): Taken Out of Context American Teen Sociality in Networked Publics, PhD Dissertation, http://www.danah.org/papers/TakenOutOfContext.pdf

- Butler, Judith (1990): Gender Trouble. Feminism and the Subversion of Identity. Routledge, New York.

- Butler, Judith (1993): Bodies that Matter. On the Discursive Limits of "Sex". Routledge, New York. - Butler, Judith (2004): Undoing Gender, Routledge, New York.

- Cromwell, Jason (1999): Transmen and FTMs: Identities, Bodies, Genders, and Sexualities. University of Illinois Press, Chicago.

- Devor, Holly (1997): FTM: female-to-male transsexuals in society. Indiana University Press, Bloomington.

- DSM (1994): The American Psychiatric Association's Diagnostic and Statistical Manual of Mental Disorders. Brunner/Mazel Publishers, Washington. - Forshee, Andrew (2008): Transgender Men: A Demographic Snapshot, i: Journal of Gay \& Lesbian Social Services, 20:3.

- Green, Jamison (2005): Part of the Package: Ideas of Masculinity among Male-Identified Transpeople, i: Men and Masculinities 7:291.
. Hines, Christine (2000): Virtual Ethnography.

SAGE publications, London.

- Johnson, Katherine (2007): Changing sex, changing self. Theorising transitions in embodied subjectivity, i: Men and Masculinities, 10 (1).

- Kaufmann, Jodi (2010): Trans-representation, i Qualitative Inquiry 16(2)

- Lange, Patricia (2007): Publicly private and privately public: social networking on YouTube, $\mathrm{i}$ Journal of Computer-Mediated Communication, 13 (1).

- Mckee, Heidi \& Porter, James (2009): The Ethics of Internet Research. A Rhetorical, Case-Based Process. Peter Lang, New York.

- Namaste, Viviane (2000): Invisible Lives: The

Erasure of Transsexual and Transgendered People. University of Chicago Press, Chicago.

- Namaste, Viviane (2005): Sex Change, Social Change. Reflections on Identity, Institutions, and Imperialism. Womens Press, Toronto.

- Prosser, Jay (1998): Second Skins: The Body Narratives of Transsexuality. Columbia University Press, New York.

- Raun, Tobias (2011): DIY Therapy: Exploring affective self-representations in trans video blogs on YouTube, i: A. Karatzogianni and A. Kuntsman (eds): Digital Cultures and the Politics of Emotion: Feelings, Affect and Technological Change, Palgrave Macmillan, Basingstoke and New York. - Rubin, Henry (2003): Self-Made Men. Identity and Embodiment among Transsexual Men, Vanderbilt University Press, Nashville.

- Sedgwick, Eve Kosofsky (2003): Paranoid Reading and Reparative Reading, or You're So Paranoid , You Probably Think This Essay Is About You, i: Touching Feeling. Affect, Pedagogy, Performativity, Duke University Press, Durham and London. - Senft, Theresa (2008): Camgirls, celebrity and community in the age of social networks, Peter Lang, New York.

. Stone, Sandy (2006): The Empire Strikes Back: A Posttranssexual Manifesto, i: Susan Stryker \& Steven Whittle (eds.): The Transgender Studies Reader. Routledge, New York. - Warner, Michael (2000): The Trouble with Normal: Sex, Politics and the Ethics of Queer Life, Free Press, New York.

\section{SUMMARY}

Man enough? Embodiment and masculinity narratives in trans video blogs on YouTube

The article takes its point of departure in 
transgender self-representations on YouTube and analyses notions of men and masculinity amongst the vloggers James, Tony and Mason. Through the lense of transgender studies the article points out the importance of paying attention to the personal stories being told and the individual renegotiations of sex and gender.

Tobias Raun, Ph.d.-studerende Institut for Kultur og Identitet Roskilde Universitet 